\title{
Primary amelanotic melanoma of the nail bed
}

\section{Pierwotnie bezbarwnikowy czerniak łożyska aparatu paznokciowego}

\author{
Aleksandra Rosiak-Buller', Anna Płaszczyńska², Martyna Sławińska², Joanna Lakomy³, Michał Sobjanek² \\ 'Dermatology Ward, Voivodship Hospital, Plock, Poland \\ 2Department of Dermatology, Venereology and Allergology, Medical University of Gdansk, Gdansk, Poland \\ ${ }^{3}$ Department of Pathomorphology, Medical University of Gdansk, Gdansk, Poland \\ 'Oddział Dermatologiczny, Wojewódzki Szpital Zespolony, Płock, Polska \\ Katedra i Klinika Dermatologii, Wenerologii i Alergologii, Gdański Uniwersytet Medyczny, Gdańsk, Polska \\ ${ }^{3}$ Katedra i Zakład Patomorfologii, Gdański Uniwersytet Medyczny, Gdańsk, Polska \\ Dermatol Rev/Przegl Dermatol 2021, 108, 290-298 \\ DOI: https://doi.org/l0.5 | |4/dr.202 I . | 0805
}

CORRESPONDING AUTHOR/
ADRES DO KORESPONDENCJI:
lek. Anna Płaszczyńska
Katedra i Klinika Dermatologii,
Wenerologii i Alergologii
Gdański Uniwersytet Medyczny
Gdańsk, Polska
e-mail: a.plaszczynskaa@gmail.com

\begin{abstract}
Introduction: Melanoma of the nail apparatus is rare in the Caucasian population and accounts for less than 1\% of all diagnosed cases of melanoma. It most often derives from melanocytes of the nail unit matrix, while the bed of the nail is rarely the starting point.
\end{abstract}

Objective: Presentation of the case of a patient with a rare form of primary amelanotic melanoma of the nail unit originating from the nail bed, and an analysis of cases described in the literature.

Case report: We present a 64-year-old man with a history of immunosuppressive treatment because of pemphigus vulgaris. The patient developed a tumor of the nail bed of the left first toe. The nail plate was removed under regional anesthesia, revealing a pigment-free tumor of the nail bed, which was excised. Nail apparatus melanoma was diagnosed on the basis of the histopathological examination.

Conclusions: The presented case and the analysis of literature data prove the necessity of histopathological verification of each pathological mass occupying the bed of the nail unit.

Key words: nail apparatus melanoma, amelanotic melanoma, acral melanoma, subungal tumor.

\section{STRESZCZENIE}

Wprowadzenie: Czerniak aparatu paznokciowego w populacji kaukaskiej występuje rzadko i stanowi mniej niż 1\% wszystkich diagnozowanych przypadków czerniaka. Najczęściej wywodzi się z melanocytów macierzy aparatu paznokciowego, natomiast niezwykle rzadko punktem wyjścia jest łożysko aparatu paznokciowego.

Cel pracy: Przedstawienie przypadku pacjenta z rzadką postacią pierwotnie bezbarwnikowego czerniaka aparatu paznokciowego wywodzącego się z łożyska aparatu paznokciowego wraz z zestawieniem przypadków opisanych $\mathrm{w}$ piśmiennictwie.

Opis przypadku: Przedstawiono przypadek 64-letniego mężczyzny leczonego immunosupresyjnie z powodu pęcherzycy zwykłej, u którego stwierdzono patologiczną masę łożyska aparatu paznokciowego palca I lewej stopy. Na podstawie wywiadu ustalono, że zmiana pojawiła się około 2 lata wcześniej. W znieczuleniu przewodowym usunięto płytkę 
paznokciową, uwidaczniając bezbarwnikowy guz łożyska paznokcia, który wycięto. Na podstawie wyniku badania histopatologicznego rozpoznano czerniaka aparatu paznokciowego.

Wnioski: Przedstawiony przypadek oraz analiza danych z piśmiennictwa potwierdzają konieczność weryfikacji histopatologicznej każdej patologicznej masy zajmującej łożysko aparatu paznokciowego.

Słowa kluczowe: czerniak aparatu paznokciowego, czerniak bezbarwnikowy, czerniak akralny, guz podpaznokciowy.

\section{INTRODUCTION}

Nail apparatus melanoma (NAM) is rare in the Caucasian population, accounting for less than $1 \%$ of all diagnosed melanomas [1]. At the Department of Dermatology, Venereology and Allergology of the Medical University of Gdansk, which for many years has specialized in the diagnostics and treatment of skin melanoma, including NAM, 1 to 3 such cases are diagnosed annually. The vast majority of NAMs are derived from melanocytes in the matrix of the nail unit. This cancer has a relatively specific clinical continuum [2]. In its earliest stage (melanoma in situ), there is an longitudinal, dark discoloration of the nail plate (melanonychia). Hutchinson's sign (dark staining of soft tissues surrounding the nail plate), deformation of the nail plate and presence of a tumor are symptoms of an invasive malignancy [1-4]. Nail bed melanocytes are an extremely rare starting point for NAM [5]. Primary amelanotic melanoma of the nail bed is very rare.

\section{OBJECTIVE}

Presentation of the case of a patient with a rare form of primary amelanotic melanoma of the nail unit originating from nail bed, along with a list of cases described in the literature.

\section{CASE REPORT}

In a 64-year-old man with skin phototype II, during systemic immunosuppression (prednisone combined with azathioprine) used due to pemphigus vulgaris limited to the glans and internal lamina of the foreskin, in clinical remission, during a routine physical examination a presence of a nodule under the nail plate of the left big toe was found (fig. $1 \mathrm{~A}$ ). According to the patient, this lesion could have been present even for 2 years, it did not cause any subjective symptoms. The history of the preceding trauma was negative.

\section{WPROWADZENIE}

Czerniak aparatu paznokciowego (nail apparatus melanoma - NAM) w populacji kaukaskiej występuje rzadko, stanowiąc mniej niż 1\% wszystkich diagnozowanych czerniaków [1]. W Klinice Dermatologii, Wenerologii i Alergologii Gdańskiego Uniwersytetu Medycznego, która od wielu lat specjalizuje się w diagnostyce i leczeniu czerniaka skóry, w tym NAM, diagnozowanych jest rocznie od 1 do 3 takich przypadków. Większość NAM wywodzi się z melanocytów macierzy aparatu paznokciowego. Nowotwór ten charakteryzuje się stosunkowo specyficznym kontinuum klinicznym [2]. W najwcześniejszym jego stadium (melanoma in situ) występuje podłużne, ciemne zabarwienie płytki paznokciowej (melanonychia). Objaw Hutchinsona (ciemne zabarwienie tkanek miękkich otaczających płytkę paznokciową), deformacja płytki paznokciowej i obecność guza to objawy inwazyjnego nowotworu [1-4]. Niezwykle rzadko punktem wyjścia NAM są melanocyty łożyska aparatu paznokciowego [5]. Pierwotnie bezbarwnikowy czerniak łożyska aparatu paznokciowego występuje bardzo rzadko.

\section{CEL PRACY}

Przedstawienie przypadku rzadkiej postaci pierwotnie bezbarwnikowego czerniaka aparatu paznokciowego wywodzącego się z łożyska paznokcia wraz z zestawieniem przypadków bezbarwnikowych NAM wywodzących się z łożyska aparatu paznokciowego opisanych w piśmiennictwie.

\section{OPIS PRZYPADKU}

U 64-letniego mężczyzny o II fototypie skóry, w trakcie systemowej immunosupresji (prednizon w skojarzeniu $\mathrm{z}$ azatiopryną) stosowanej z powodu pęcherzycy zwyczajnej ograniczonej do żołędzi i wewnętrznej blaszki napletka, w stanie remisji klinicznej, podczas rutynowego badania fizykalnego stwierdzono obecność guzka pod płytką paznokciową palucha lewego (ryc. $1 \mathrm{~A})$. Według pacjenta zmiana mogła być obecna nawet od 2 lat, 
Under perineural anesthesia and local ischemia after removing the nail plate, in the distal part of the nailbed was revealed the colorless nodule (fig. $1 \mathrm{C}$ ), which was diagnostically excised with borders of macroscopically unchanged tissues. Histopathological examination indicated acral melanoma in the vertical growth phase with ulceration and regression features, with an infiltration depth of $1.9 \mathrm{~mm}$ according to Breslow, and grade IV according to the Clark scale. The mitotic index was 4 mitosis $/ 1 \mathrm{~mm}^{2}$. Moderately abundant lymphocytic infiltrates (TILs non-brisk) were present. The stage was assessed as pT2bNxMx.

The patient was referred to the Department of Oncological Surgery for toe amputation at the metatarsophalangeal level and sentinel node biopsy. The sentinel node was free of melanoma cells. During the 26-month follow-up, no signs of local recurrence or distant metastases were found.

\section{DISCUSSION}

A significant progress has been made recently in the early diagnosis of cutaneous melanoma. This is a result of the ever-growing social awareness, including awareness of medical personnel, of skin cancer profile and improved diagnostic tools [6]. Unfortunately, according to the authors, acral melanomas are diagnosed too late. It is related to their rare occurrence, frequent omission of acral areas during a physical examination and lack of awareness of neoplasms occurring in this area $[7,8]$.

Subungal tumors are particularly difficult to diagnose due to anatomical circumstances. Dermoscopy is nie przysparzała dolegliwości subiektywnych. Wywiad w kierunku poprzedzającego urazu był ujemny.

$\mathrm{W}$ znieczuleniu przewodowym i w miejscowym niedokrwieniu, po zdjęciu płytki paznokciowej, w dystalnej części łożyska stwierdzono bezbarwnikowy guzek (ryc. 1 C), który wycięto diagnostycznie w granicach tkanek makroskopowo niezmienionych. W obrazie histopatologicznym wykazano utkanie czerniaka akralnego w wertykalnej fazie wzrostu z obecnym owrzodzeniem oraz cechami regresji, o głębokości nacieku 1,9 mm według Breslowa (IV stopień według skali Clarka). Indeks mitotyczny wynosił 4 mitozy $/ 1 \mathrm{~mm}^{2}$. Obecne były średnio obfite nacieki limfocytarne (TILs non-brisk). Stopień zaawansowania oceniono na $\mathrm{pT} 2 \mathrm{bNxMx}$.

Pacjenta skierowano do Kliniki Chirurgii Onkologicznej w celu amputacji palucha na poziomie stawu śródstopno-paliczkowego oraz wykonania procedury biopsji węzła wartowniczego. Węzeł wartowniczy był wolny od komórek czerniaka. W czasie 26-miesięcznej obserwacji nie stwierdzono cech wznowy miejscowej ani przerzutów odległych.

\section{OMÓWIENIE}

W ostatnich latach zauważalny jest istotny postęp we wczesnej diagnostyce czerniaka skóry. Wynika to ze stale rosnącej świadomości społecznej, w tym personelu medycznego, dotyczącej profilaktyki nowotworów skóry oraz coraz doskonalszych narzędzi diagnostycznych [6]. Niestety czerniaki akralne rozpoznawane są zdaniem autorów zbyt późno. Związane jest to z rzadkością ich występowania, częstym pomijaniem okolic
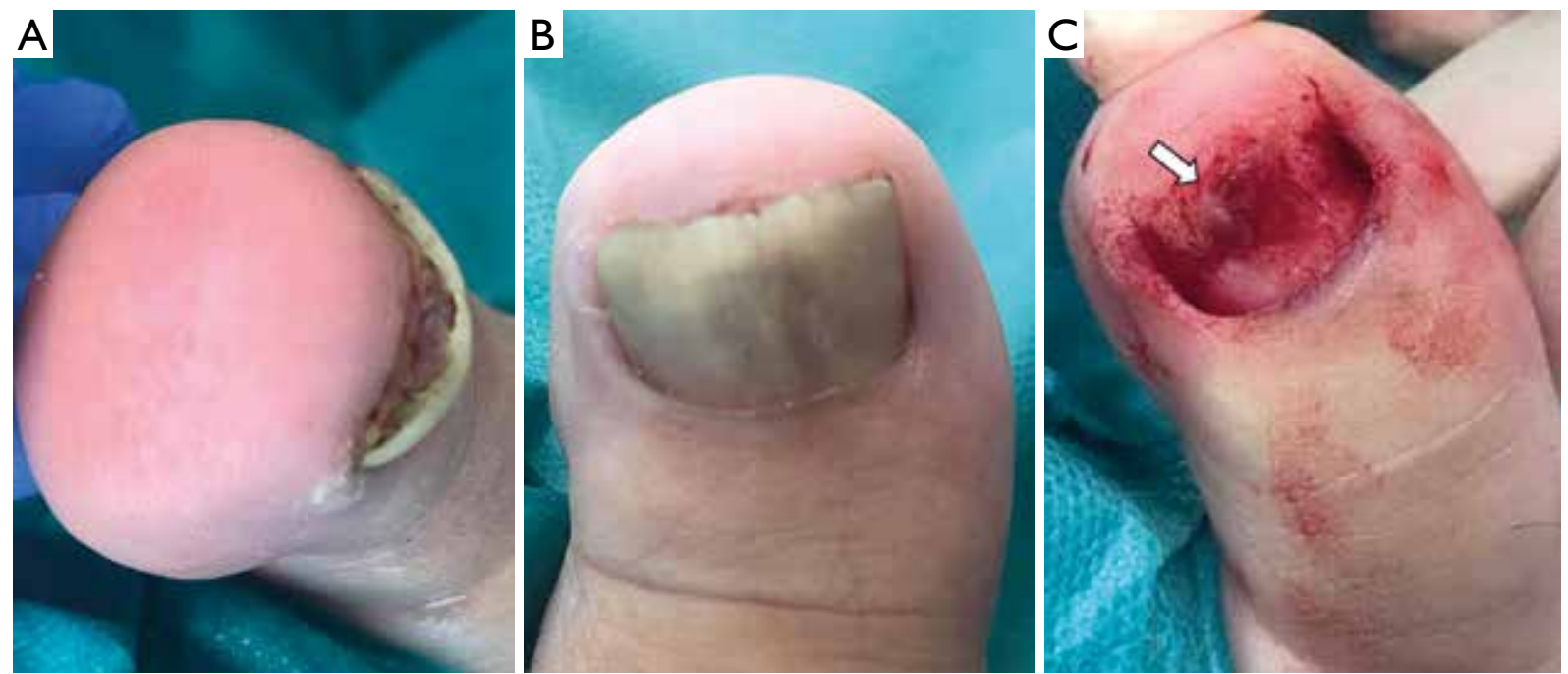

Figure I. A - Clinical presentation - nail bed tumor with secondary onycholysis. B - Chromonychia and onycholysis secondary to the presence of a pathological mass occupying the bed of the nail apparatus. C - Clinical presentation after removal of the nail plate. Visible, poorly demarcated, irregular in shape, amelanotic tumor involving the middle and distal part of the nail apparatus bed (arrow)

Rycina I. A - Obraz kliniczny - guz łożyska aparatu paznokciowego z wtórną onycholizą. B - Chromonychia i onycholiza wtórne do obecności patologicznej masy zajmującej łożysko aparatu paznokciowego. C - Obraz kliniczny po usunięciu płytki paznokciowej. Widoczny nieostro odgraniczony, nieregularnego kształtu guz bezbarwnikowy obejmujący środkową i dystalną część łożyska aparatu paznokciowego (strzałka) 
only of auxiliary importance in their diagnosis. Table 1 lists cases of amelanotic melanoma originating from the nailbed, described in the English-language literature [9-23]. This tumor has no pathognomonic clinical features. Moreover, clinical differentiation of subungal tumors (pyogenic granuloma, squamous cell carcinoma, and amelanotic melanoma) is practically impossible. Whenever a tumor of the nail bed is suspected, a biopsy should be performed after removing the nail plate. Presence of pathogenic microorganisms does not release a clinician from the necessity of histopathological verification of the lesion.

\section{CONCLUSIONS}

The presented case and the quoted literature data prove that it is necessary to differentiate each lesion that deforms the nail plate from a malignant tumor.

\section{CONFLICT OF INTEREST}

The authors declare no conflict of interest. akralnych podczas badania fizykalnego oraz nieświadomością występowania nowotworów w tej okolicy $[7,8]$.

Guzy podpłytkowe są sprawą szczególnie trudną diagnostycznie $\mathrm{z}$ uwagi na uwarunkowania anatomiczne. Dermoskopia $w$ ich diagnostyce ma znaczenie jedynie pomocnicze. $W$ tabeli 1 przedstawiono opisane $\mathrm{w}$ piśmiennictwie anglojęzycznym przypadki bezbarwnikowego czerniaka wywodzącego się z łożyska aparatu paznokciowego [9-23]. Nowotwór ten nie ma patognomonicznych cech klinicznych. Ponadto kliniczne różnicowanie guzów podpłytkowych (ziarniniak naczyniowy, rak płaskonabłonkowy, czerniak bezbarwnikowy) jest praktycznie niemożliwe. W każdym przypadku podejrzenia guza łożyska aparatu paznokciowego należy przeprowadzić biopsję po wcześniejszym zdjęciu płytki paznokciowej. Stwierdzenie obecności patogennych drobnoustrojów nie zwalnia klinicysty z konieczności weryfikacji histopatologicznej zmiany.

\section{WNIOSKI}

Prezentowany przypadek oraz przytoczone dane z piśmiennictwa potwierdzają konieczność różnicowania z nowotworem złośliwym każdej zmiany deformującej płytkę paznokciową.

\section{KONFLIKT INTERESÓW}

Autorzy nie zgłaszają konfliktu interesów.

Table I. List of cases of primary amelanotic melanoma of the nail apparatus originating from the nail bed, described in the English-language literature Tabela I. Zestawienie przypadków pierwotnie bezbarwnikowego czerniaka aparatu paznokciowego wywodzącego się z łożyska paznokcia opisanych w piśmienictwie anglojęzycznym

\begin{tabular}{|c|c|c|c|c|c|c|c|}
\hline $\begin{array}{l}\text { Authors/ } \\
\text { Autorzy }\end{array}$ & $\begin{array}{l}\text { Clinical presentation/ } \\
\text { Obraz kliniczny }\end{array}$ & $\begin{array}{l}\text { Advancement/ } \\
\text { Zaawansowanie }\end{array}$ & $\begin{array}{l}\text { Localization/ } \\
\text { Lokalizacja }\end{array}$ & $\begin{array}{c}\text { Medical } \\
\text { history until } \\
\text { the diagnosis/ } \\
\text { Długość wywiadu } \\
\text { do momentu } \\
\text { rozpoznania }\end{array}$ & $\begin{array}{c}\text { Risk } \\
\text { factors/ } \\
\text { Czynniki } \\
\text { ryzyka }\end{array}$ & $\begin{array}{l}\text { Preliminary } \\
\text { clinical } \\
\text { diagnosis/ } \\
\text { Wstępne } \\
\text { rozpoznanie } \\
\text { kliniczne }\end{array}$ & Notes/Uwagi \\
\hline $\begin{array}{l}\text { Ishii et al. } \\
\text { Dermatol } \\
\text { Online J } \\
2018 \text { [9] }\end{array}$ & $\begin{array}{l}\text { Yellowish nail plate with longitudinal } \\
\text { ridges on the surface, with a partial } \\
\text { absence of a nail plate on the medial } \\
\text { side/Zażółcona płytka paznokciowa } \\
\text { z podłużnymi bruzdami na } \\
\text { powierzchni, z częściowym brakiem } \\
\text { płytki paznokciowej po stronie } \\
\text { przyśrodkowej }\end{array}$ & $\begin{array}{c}\text { Invasive } \\
\text { melanoma/ } \\
\text { Czerniak } \\
\text { inwazyjny }\end{array}$ & $\begin{array}{c}\text { Ist finger of } \\
\text { the left hand/ } \\
\text { Palec I. ręki } \\
\text { lewej }\end{array}$ & 5 years/5 lat & $\begin{array}{l}\text { Trauma/ } \\
\text { Uraz }\end{array}$ & Mycosis/Grzybica & - \\
\hline $\begin{array}{l}\text { Rangwala } \\
\text { et al. } \\
\text { Dermatol } \\
\text { Online J } \\
2011 \text { [10] }\end{array}$ & $\begin{array}{l}\text { Absence of regrowth of the } \\
\text { nail plate after its loss caused by } \\
\text { trauma sustained I } 5 \text { months } \\
\text { earlier, red granulation tissue in } \\
\text { the nail bed, periungual edema, } \\
\text { erythema reaching the proximal } \\
\text { interphalangeal joint/Brak odrostu } \\
\text { płytki paznokciowej po jej utracie } \\
\text { spowodowanej urazem } \\
\text { I } 5 \text { miesięcy wcześniej, w obrębie } \\
\text { łożyska paznokciowego czerwona } \\
\text { ziarnina, obrzęk okołopaznokciowy, } \\
\text { rumień sięgający do stawu } \\
\text { międzypaliczkowego bliższego }\end{array}$ & $\begin{array}{l}\text { Invasive } \\
\text { melanoma/ } \\
\text { Czerniak } \\
\text { inwazyjny }\end{array}$ & $\begin{array}{l}5^{\text {th }} \text { finger of } \\
\text { the left hand/ } \\
\text { Palec 5. ręki } \\
\text { lewej }\end{array}$ & $\begin{array}{l}\text { I } 5 \text { months/ } \\
\text { I5 miesięcy }\end{array}$ & $\begin{array}{l}\text { Trauma/ } \\
\text { Uraz }\end{array}$ & $\begin{array}{l}\text { Paronychia } \\
\text { secondary to } \\
\text { fungal or bacterial } \\
\text { infection/ } \\
\text { Zanokcica na } \\
\text { podłożu infekcji } \\
\text { grzybiczej lub } \\
\text { bakteryjnej }\end{array}$ & - \\
\hline
\end{tabular}


Table I. Cont

Tabela I. Cd.

\begin{tabular}{|c|c|c|c|c|c|c|c|}
\hline $\begin{array}{l}\text { Authors/ } \\
\text { Autorzy }\end{array}$ & $\begin{array}{l}\text { Clinical presentation/ } \\
\text { Obraz kliniczny }\end{array}$ & $\begin{array}{l}\text { Advancement/ } \\
\text { Zaawansowanie }\end{array}$ & $\begin{array}{l}\text { Localization/ } \\
\text { Lokalizacja }\end{array}$ & $\begin{array}{l}\text { Medical } \\
\text { history until } \\
\text { the diagnosis/ } \\
\text { Długość wywiadu } \\
\text { do momentu } \\
\text { rozpoznania }\end{array}$ & $\begin{array}{c}\text { Risk } \\
\text { factors/ } \\
\text { Czynniki } \\
\text { ryzyka }\end{array}$ & $\begin{array}{l}\text { Preliminary } \\
\text { clinical } \\
\text { diagnosis/ } \\
\text { Wstępne } \\
\text { rozpoznanie } \\
\text { kliniczne }\end{array}$ & Notes/Uwagi \\
\hline $\begin{array}{l}\text { Cahill } \\
\text { et al. Foot } \\
\text { Ankle Surg } \\
2009[1 \text { l] }\end{array}$ & $\begin{array}{l}\text { Lateral ingrowth of the nail plate } \\
\text { with the presence of tissue } \\
\text { imitating granulation tissue/Boczne } \\
\text { wrastanie płytki paznokciowej } \\
\text { z obecnością tkanki imitującej } \\
\text { ziarninę }\end{array}$ & $\begin{array}{l}\text { Invasive } \\
\text { melanoma/ } \\
\text { Czerniak } \\
\text { inwazyjny }\end{array}$ & $\begin{array}{l}\text { | st toe of the } \\
\text { right foot/ } \\
\text { Palec I. stopy } \\
\text { prawej }\end{array}$ & $\begin{array}{l}\text { 6-7 months/ } \\
\text { 6-7 miesięcy }\end{array}$ & - & $\begin{array}{l}\text { Ingrowing } \\
\text { toenail/ } \\
\text { Wrastający } \\
\text { paznokieć }\end{array}$ & - \\
\hline $\begin{array}{l}\text { Ghariani } \\
\text { et al. } \\
\text { Dermatol } \\
\text { Online J } \\
2008 \text { [12] }\end{array}$ & $\begin{array}{l}\text { Red, brittle, easily bleeding nodule } \\
\text { located in the distal part of the } \\
\text { nail bed, causing onycholysis/ } \\
\text { Czerwony, kruchy, tatwo } \\
\text { krwawiący guzek, zlokalizowany } \\
\text { w dystalnej części łożyska } \\
\text { paznokcia, odwarstwiający } \\
\text { płytkę paznokciową }\end{array}$ & $\begin{array}{c}\text { No data } \\
\text { on tumor } \\
\text { advancement } \\
\text { stage/Brak } \\
\text { danych } \\
\text { o stopniu } \\
\text { zaawansowania } \\
\text { nowotworu }\end{array}$ & $\begin{array}{c}4^{\text {th }} \text { finger } \\
\text { of the right } \\
\text { hand/Palec } 4 \text {. } \\
\text { ręki prawej }\end{array}$ & I month/I miesiąc & $\begin{array}{c}\text { Trauma/ } \\
\text { Uraz }\end{array}$ & $\begin{array}{c}\text { Pyogenic } \\
\text { granuloma/ } \\
\text { Ziarniniak } \\
\text { ropotwórczy }\end{array}$ & - \\
\hline $\begin{array}{l}\text { Lemont } \\
\text { et al. J Am } \\
\text { Podiatr } \\
\text { Med Assoc } \\
2002 \text { [13] }\end{array}$ & $\begin{array}{c}\text { Lateral nail fold border tumor } \\
\text { imitating lateral ingrowth of the nail } \\
\text { plate, paronychia/Guz pogranicza } \\
\text { bocznego wału paznokciowego } \\
\text { imitujący boczne wrastanie płytki } \\
\text { paznokciowej, zanokcica }\end{array}$ & $\begin{array}{l}\text { Invasive } \\
\text { melanoma/ } \\
\text { Czerniak } \\
\text { inwazyjny }\end{array}$ & $\begin{array}{l}\text { Ist toe of the } \\
\text { left foot/Palec } \\
\text { I. stopy lewej }\end{array}$ & $\begin{array}{c}\text { No data/ } \\
\text { Brak danych }\end{array}$ & - & $\begin{array}{l}\text { Ingrowing } \\
\text { toenail/ } \\
\text { Wrastający } \\
\text { paznokieć }\end{array}$ & - \\
\hline $\begin{array}{l}\text { Matsuta } \\
\text { et al. } \\
\text { J Cutan } \\
\text { Pathol } \\
\text { 1990 [14] }\end{array}$ & $\begin{array}{l}3 / 4 \text { of the surface of the nail plate } \\
\text { is missing, the nail bed is occupied } \\
\text { by a tumor imitating granulation } \\
\text { tissue/Brak } 3 / 4 \text { powierzchni płytki } \\
\text { paznokciowej, zajęcie łożyska } \\
\text { aparatu paznokciowego przez guz } \\
\text { imitujący ziarninę }\end{array}$ & $\begin{array}{l}\text { Invasive } \\
\text { melanoma/ } \\
\text { Czerniak } \\
\text { inwazyjny }\end{array}$ & $\begin{array}{l}\text { Ist finger of } \\
\text { the left hand/ } \\
\text { Palec I. ręki } \\
\text { lewej }\end{array}$ & $\begin{array}{l}\text { 4-5 months/ } \\
\text { 4-5 miesięcy }\end{array}$ & $\begin{array}{c}\text { Trauma/ } \\
\text { Uraz }\end{array}$ & $\begin{array}{c}\text { Granulating } \\
\text { post-traumatic } \\
\text { wound/ } \\
\text { Ziarninująca rana } \\
\text { pourazowa }\end{array}$ & - \\
\hline $\begin{array}{l}\text { Nakamura } \\
\text { et al. } \\
\text { J Dermatol } \\
\text { | } 985 \text { [15] }\end{array}$ & $\begin{array}{l}\text { Ulcerative, pale red tumor of the } \\
\text { nail bed, half of the nail is missing/ } \\
\text { Wrzodziejący, bladoczerwony guz } \\
\text { tożyska aparatu paznokciowego, } \\
\text { brak połowy płytki paznokciowej }\end{array}$ & $\begin{array}{l}\text { No data } \\
\text { on tumor } \\
\text { advancement } \\
\text { stage/Brak } \\
\text { danych } \\
\text { o stopniu } \\
\text { zaawansowania } \\
\text { nowotworu }\end{array}$ & $\begin{array}{c}\text { I ft finger } \\
\text { of the right } \\
\text { hand/Palec I. } \\
\text { ręki prawej }\end{array}$ & $\begin{array}{l}6 \text { months/ } \\
6 \text { miesięcy }\end{array}$ & $\begin{array}{l}\text { Trauma/ } \\
\text { Uraz }\end{array}$ & $\begin{array}{l}\text { The differential } \\
\text { diagnosis in this } \\
\text { case included } \\
\text { squamous cell car- } \\
\text { cinoma, pyogenic } \\
\text { granuloma, and } \\
\text { other granulomas/ } \\
\text { Diagnostyka } \\
\text { różnicowa } \\
\text { w tym przypadku } \\
\text { obejmowała raka } \\
\text { kolczystokomór- } \\
\text { kowego, ziarniaka } \\
\text { ropotwórczego } \\
\text { i inne ziarniniaki }\end{array}$ & $\begin{array}{c}\text { Squamous cell } \\
\text { carcinoma was } \\
\text { suspected based } \\
\text { on the histopato- } \\
\text { logical examination } \\
\text { of the biopsy } \\
\text { specimen/Na } \\
\text { podstawie badania } \\
\text { histopatolo- } \\
\text { gicznego bioptatu } \\
\text { podejrzewano } \\
\text { raka kolczysto- } \\
\text { komórkowego } \\
\text { Histopatological } \\
\text { and histochemical } \\
\text { examination of } \\
\text { tissues collected } \\
\text { during radical } \\
\text { surgery allowed } \\
\text { for the diagnosis of } \\
\text { melanoma/Badanie } \\
\text { histopatologiczne } \\
\text { i histochemiczne } \\
\text { tkanek pobranych } \\
\text { podczas radykalne- } \\
\text { go zabiegu pozwo- } \\
\text { liło na rozpoznanie } \\
\text { czerniaka }\end{array}$ \\
\hline
\end{tabular}


Table I. Cont.

Tabela I. Cd.

\begin{tabular}{|c|c|c|c|c|c|c|c|}
\hline $\begin{array}{l}\text { Authors/ } \\
\text { Autorzy }\end{array}$ & $\begin{array}{l}\text { Clinical presentation/ } \\
\text { Obraz kliniczny }\end{array}$ & $\begin{array}{l}\text { Advancement/ } \\
\text { Zaawansowanie }\end{array}$ & $\begin{array}{l}\text { Localization/ } \\
\text { Lokalizacja }\end{array}$ & $\begin{array}{c}\text { Medical } \\
\text { history until } \\
\text { the diagnosis/ } \\
\text { Długość wywiadu } \\
\text { do momentu } \\
\text { rozpoznania }\end{array}$ & $\begin{array}{l}\text { Risk } \\
\text { factors/ } \\
\text { Czynniki } \\
\text { ryzyka }\end{array}$ & $\begin{array}{l}\text { Preliminary } \\
\text { clinical } \\
\text { diagnosis/ } \\
\text { Wstępne } \\
\text { rozpoznanie } \\
\text { kliniczne }\end{array}$ & Notes/Uwagi \\
\hline $\begin{array}{l}\text { Riahi et al. } \\
\text { Cureus } \\
2018[16]\end{array}$ & $\begin{array}{l}\text { Nail plate dystrophy/Dystrofia } \\
\text { płytki paznokciowej }\end{array}$ & $\begin{array}{l}\text { Invasive } \\
\text { melanoma/ } \\
\text { Czerniak } \\
\text { inwazyjny }\end{array}$ & $\begin{array}{l}4^{\text {th }} \text { finger of } \\
\text { the left hand/ } \\
\text { Palec 4. ręki } \\
\text { lewej }\end{array}$ & 4 years/4 lata & $\begin{array}{l}\text { Trauma/ } \\
\text { Uraz }\end{array}$ & Mycosis/Grzybica & - \\
\hline $\begin{array}{l}\text { Winslet } \\
\text { et al. } \\
\text { Postgrad } \\
\text { Med J }\end{array}$ & $\begin{array}{l}\text { Post-traumatic, pale, proliferating } \\
\text { tumor of the nail bed, destroying } \\
\text { the nail plate, features of infection/ } \\
\text { Pourazowy, blady, proliferujący guz }\end{array}$ & $\begin{array}{l}\text { Invasive } \\
\text { melanoma/ } \\
\text { Czerniak } \\
\text { inwazyjny }\end{array}$ & $\begin{array}{l}\text { Ist toe of the } \\
\text { left foot/Palec } \\
\text { ।. stopy lewej }\end{array}$ & I year/I rok & $\begin{array}{c}\text { Trauma/ } \\
\text { Uraz }\end{array}$ & $\begin{array}{l}\text { Ingrowing } \\
\text { toenail/ } \\
\text { Wrastający } \\
\text { paznokieć }\end{array}$ & - \\
\hline
\end{tabular}

1990 [17] - lożyska aparatu paznokciowe niszczący płytkę paznokciową. cechy infekcji

\begin{tabular}{|c|c|c|c|c|c|c|}
\hline $\begin{array}{l}\text { Arican } \\
\text { et al. Saudi } \\
\text { Med J } \\
2006 \text { [18] }\end{array}$ & $\begin{array}{c}\text { Yellowish, papillary tissue, bleeding } \\
\text { and oozing, involving most } \\
\text { of the nail bed with necrotic areas } \\
\text { and accompanying swelling } \\
\text { of surrounding tissues, absence } \\
\text { of the nail plate/ } \\
\text { Żółtawa, brodawkująca tkanka, } \\
\text { krwawiąca i sącząca, zajmująca } \\
\text { większą część łożyska aparatu } \\
\text { paznokciowego z obecnością } \\
\text { obszarów martwiczych } \\
\text { i towarzyszącym obrzękiem } \\
\text { otaczających tkanek, brak płytki } \\
\text { paznokciowej }\end{array}$ & $\begin{array}{l}\text { Invasive } \\
\text { melanoma/ } \\
\text { Czerniak } \\
\text { inwazyjny }\end{array}$ & $\begin{array}{c}\text { Ist toe of the } \\
\text { right foot/ } \\
\text { Palec I. stopy } \\
\text { prawej }\end{array}$ & $\begin{array}{l}9 \text { months/ } \\
9 \text { miesięcy }\end{array}$ & - & $\begin{array}{c}\text { Differential di- } \\
\text { agnosis included } \\
\text { pyogenic granu- } \\
\text { loma, squamous } \\
\text { cell carcinoma, } \\
\text { amelanotic } \\
\text { melanoma, deep } \\
\text { mycosis, cuta- } \\
\text { neous leishman- } \\
\text { iasis/Diagnos- } \\
\text { tyka różnicowa } \\
\text { obejmowała } \\
\text { ziarniniaka } \\
\text { ropotwórczego, } \\
\text { raka kolczysto- } \\
\text { komórkowego, } \\
\text { czerniaka bez- } \\
\text { barwnikowego, } \\
\text { grzybicę głęboką, } \\
\text { leiszmaniozę } \\
\text { skórna }\end{array}$ \\
\hline
\end{tabular}

\begin{tabular}{|c|c|c|c|c|c|c|c|}
\hline $\begin{array}{l}\text { André } \\
\text { et al. Arch } \\
\text { Dermatol } \\
2010[19]\end{array}$ & $\begin{array}{l}\text { Presence of longitudinal ridges } \\
\text { and thinning of the distal } 2 / 3 \text { of } \\
\text { the nail plate in the middle part, } \\
\text { also distal onycholysis, few linear } \\
\text { subungual petechiae and a discrete } \\
\text { fracture of the distal edge of the } \\
\text { nail plate/Obecność podłużnych } \\
\text { bruzd oraz ścieńczenie w obrębie } \\
\text { dystalnych } 2 / 3 \text { płytki paznokciowej } \\
\text { w części środkowej, ponadto } \\
\text { dystalna onycholiza, nieliczne linijne } \\
\text { wybroczyny podpaznokciowe oraz } \\
\text { dyskretne pęknięcie dystalnego } \\
\text { brzegu płytki paznokciowej }\end{array}$ & $\begin{array}{l}\text { Melanoma in } \\
\text { situ/Czerniak } \\
\quad \text { in situ }\end{array}$ & $\begin{array}{c}\text { I st finger } \\
\text { of the right } \\
\text { hand/Palec I. } \\
\text { ręki prawej }\end{array}$ & $\begin{array}{l}18 \text { months/ } \\
18 \text { miesięcy }\end{array}$ & - & $\begin{array}{l}\text { Mycosis; after } \\
\text { a year of inef- } \\
\text { fective antifungal } \\
\text { treatment, } \\
\text { Bowen's disease } \\
\text { was suspected/ } \\
\text { Grzybica; } \\
\text { po roku nie- } \\
\text { skutecznego } \\
\text { leczenia prze- } \\
\text { ciwgrzybiczego } \\
\text { wysnuto podej- } \\
\text { rzenie choroby } \\
\text { Bowena }\end{array}$ & - \\
\hline
\end{tabular}


Table I. Cont.

Tabela I. Cd.

\begin{tabular}{|c|c|c|c|c|c|c|c|}
\hline $\begin{array}{l}\text { Authors/ } \\
\text { Autorzy }\end{array}$ & $\begin{array}{l}\text { Clinical presentation/ } \\
\text { Obraz kliniczny }\end{array}$ & $\begin{array}{l}\text { Advancement/ } \\
\text { Zaawansowanie }\end{array}$ & $\begin{array}{l}\text { Localization/ } \\
\text { Lokalizacja }\end{array}$ & $\begin{array}{c}\text { Medical } \\
\text { history until } \\
\text { the diagnosis/ } \\
\text { Długość wywiadu } \\
\text { do momentu } \\
\text { rozpoznania }\end{array}$ & $\begin{array}{c}\text { Risk } \\
\text { factors/ } \\
\text { Czynniki } \\
\text { ryzyka }\end{array}$ & $\begin{array}{l}\text { Preliminary } \\
\text { clinical } \\
\text { diagnosis/ } \\
\text { Wstępne } \\
\text { rozpoznanie } \\
\text { kliniczne }\end{array}$ & Notes/Uwagi \\
\hline $\begin{array}{l}\text { André } \\
\text { et al. Arch } \\
\text { Dermatol } \\
2010 \text { [19] }\end{array}$ & $\begin{array}{l}\text { The area of dystrophy in the central } \\
\text { part of the nail plate, separated } \\
\text { by two longitudinal ridges from the } \\
\text { lateral, normal parts of the plate, } \\
\text { and also slightly increased } \\
\text { subungual keratosis/ } \\
\text { Obszar dystrofii w środkowej } \\
\text { czéści płytki paznokciowej, } \\
\text { oddzielony dwiema podłużnymi } \\
\text { bruzdami od bocznych, } \\
\text { prawidłowych części płytki, } \\
\text { ponadto nieznacznie nasilone } \\
\text { rogowacenie podpaznokciowe }\end{array}$ & $\begin{array}{l}\text { Melanoma in } \\
\text { situ/Czerniak } \\
\text { in situ }\end{array}$ & $\begin{array}{l}2^{\text {nd }} \text { finger of } \\
\text { the left hand/ } \\
\text { Palec 2. ręki } \\
\text { lewej }\end{array}$ & $\begin{array}{l}6 \text { months/ } \\
6 \text { miesięcy }\end{array}$ & - & $\begin{array}{l}\text { Lichen planus/ } \\
\text { Liszaj płaski }\end{array}$ & $\begin{array}{c}\text { An in-depth } \\
\text { medical history } \\
\text { determined that } \\
\text { two longitudinal } \\
\text { ridges of the nail } \\
\text { plate were initially } \\
\text { light gray/ } \\
\text { W pogtębionym } \\
\text { wywiadzie } \\
\text { lekarskim ustalono, } \\
\text { że dwie podłużne } \\
\text { bruzdy płytki } \\
\text { paznokciowej } \\
\text { były początkowo } \\
\text { jasnoszare }\end{array}$ \\
\hline
\end{tabular}

André Splitting of the nail plate in its

et al. Arch lateral part, thinning of the nail

Dermatol plate, presence of longitudinal

$2010[19] \quad$ ridges on the surface of the nail plate and a few subungual petechiae/Rozszczepienie płytki paznokciowej w jej bocznej części, ścieńczenie płytki paznokciowej, obecność podłużnych bruzd na powierzchni płytki paznokciowej oraz nielicznych wybroczyn podpaznokciowych

$\begin{array}{ccc}\begin{array}{c}\text { Melanoma in } \\ \text { situ/Czerniak } \\ \text { in situ }\end{array} & \begin{array}{c}\text { Ist finger } \\ \text { of the right } \\ \text { hand/Palec I. } \\ \text { ręki prawej }\end{array} & \begin{array}{c}\text { Over } 6 \text { months/ } \\ \text { Powyżej } \\ 6 \text { miesięcy }\end{array} \\ \end{array}$

Lichen planus/ Initially, there was

Liszaj płaski a longitudinal split

in the lateral part

of the nail plate and a red spot

within the bottom

of the nail plate

were observed;

glomus tumor

was excluded

on magnetic

resonance imaging/

Początkowo

obserwowano

podłużne

rozszczepienie

w bocznej części

płytki paznokciowej

oraz czerwoną

plamkę w obrębie

obłączka;

w badaniu

rezonansem

magnetycznym

wykluczono

kłębczaka

\begin{tabular}{|c|c|c|c|c|c|c|c|}
\hline $\begin{array}{l}\text { Girgenti } \\
\text { et al. Acta } \\
\text { Derm } \\
\text { Venereol } \\
2013 \text { [20] }\end{array}$ & $\begin{array}{l}\text { Ulceration of the proximal nail } \\
\text { fold; two purple-blue nodules on } \\
\text { the dorsal surface of the finger/ } \\
\text { Owrzodzenie proksymalnego wału } \\
\text { paznokciowego; dwa fioletowo- } \\
\text { niebieskie guzki na grzbietowej } \\
\text { powierzchni palca }\end{array}$ & $\begin{array}{c}\text { Invasive } \\
\text { melanoma/ } \\
\text { Czerniak } \\
\text { inwazyjny }\end{array}$ & $\begin{array}{l}5^{\text {th }} \text { toe of the } \\
\text { left foot/Palec } \\
\text { 5. stopy lewej }\end{array}$ & $\begin{array}{l}\text { I } 2 \text { months/ } \\
\text { I } 2 \text { miesięcy }\end{array}$ & $\begin{array}{c}\text { Trauma/ } \\
\text { Uraz }\end{array}$ & - & - \\
\hline $\begin{array}{l}\text { Harwood } \\
\text { et al. } \\
\text { J Am Acad } \\
\text { Dermatol } \\
2008 \text { [2 I] }\end{array}$ & $\begin{array}{c}\text { Erythronychia band } 5.5 \mathrm{~mm} \\
\text { wide, distal onycholysis and distal } \\
\text { brown subungal discoloration/ } \\
\text { Pasmo erytronychii szerokości } \\
5,5 \mathrm{~mm} \text {, dystalna onycholiza oraz } \\
\text { dystalne brązowe przebarwienie } \\
\text { podpaznokciowe }\end{array}$ & $\begin{array}{c}\text { Melanoma in } \\
\text { situ/Czerniak } \\
\text { in situ }\end{array}$ & $\begin{array}{c}\text { Ist finger of } \\
\text { the left hand/ } \\
\text { Palec I. ręki } \\
\text { lewej }\end{array}$ & $\begin{array}{l}\text { 3-4 months/ } \\
\text { 3-4 miesiące }\end{array}$ & - & - & - \\
\hline
\end{tabular}


Table I. Cont.

Tabela I. Cd.

\begin{tabular}{|c|c|c|c|c|c|c|c|}
\hline $\begin{array}{l}\text { Authors/ } \\
\text { Autorzy }\end{array}$ & $\begin{array}{l}\text { Clinical presentation/ } \\
\text { Obraz kliniczny }\end{array}$ & $\begin{array}{l}\text { Advancement/ } \\
\text { Zaawansowanie }\end{array}$ & $\begin{array}{l}\text { Localization/ } \\
\text { Lokalizacja }\end{array}$ & $\begin{array}{l}\text { Medical } \\
\text { history until } \\
\text { the diagnosis/ } \\
\text { Długość wywiadu } \\
\text { do momentu } \\
\text { rozpoznania }\end{array}$ & $\begin{array}{c}\text { Risk } \\
\text { factors/ } \\
\text { Czynniki } \\
\text { ryzyka }\end{array}$ & $\begin{array}{l}\text { Preliminary } \\
\text { clinical } \\
\text { diagnosis/ } \\
\text { Wstępne } \\
\text { rozpoznanie } \\
\text { kliniczne }\end{array}$ & Notes/Uwagi \\
\hline $\begin{array}{l}\text { Boni et al. } \\
\text { J Cutan } \\
\text { Pathol } \\
2015 \text { [22] }\end{array}$ & $\begin{array}{c}\text { Distal onycholysis accompanied } \\
\text { by erythronychia in the proximal } \\
\text { part of the nail plate/Dystalna } \\
\text { onycholiza z towarzyszącą } \\
\text { erytronychią w części proksymalnej } \\
\text { płytki paznokciowej }\end{array}$ & $\begin{array}{l}\text { Melanoma in } \\
\text { situ/Czerniak } \\
\text { in situ }\end{array}$ & $\begin{array}{c}\text { Ist finger } \\
\text { of the right } \\
\text { hand/Palec I. } \\
\text { ręki prawej }\end{array}$ & $\begin{array}{l}17 \text { months/ } \\
17 \text { miesięcy }\end{array}$ & $\begin{array}{c}\text { Trauma/ } \\
\text { Uraz }\end{array}$ & $\begin{array}{l}\text { Post-traumatic } \\
\text { onychodystro- } \\
\text { phy, mycosis/ } \\
\text { Onychodystrofia } \\
\text { pourazowa, } \\
\text { grzybica }\end{array}$ & - \\
\hline $\begin{array}{l}\text { Dika et al. } \\
\text { J Am Acad } \\
\text { Dermatol } \\
2016 \text { [23] }\end{array}$ & $\begin{array}{c}\text { Nodule of the nail bed apparatus } \\
\text { extending from proximal nail fold } \\
\text { to hyponychium, splitting the } \\
\text { nail plate/Guzek łożyska aparatu } \\
\text { paznokciowego rozciągający } \\
\text { się od proksymalnego wału } \\
\text { paznokciowego do hyponychium, } \\
\text { rozszczepiający płytkę } \\
\text { paznokciową }\end{array}$ & $\begin{array}{l}\text { Invasive } \\
\text { melanoma/ } \\
\text { Czerniak } \\
\text { inwazyjny }\end{array}$ & $\begin{array}{c}\text { No data/Brak } \\
\text { danych }\end{array}$ & $\begin{array}{l}6 \text { months/ } \\
6 \text { miesięcy }\end{array}$ & - & $\begin{array}{l}\text { Mycosis/ } \\
\text { Grzybica }\end{array}$ & - \\
\hline
\end{tabular}

\section{References}

\section{Piśmienictwo}

1. Sobjanek M., Michajłowski I., Biernat W., Drucis K., Włodarkiewicz A., Roszkiewicz J.: Nail apparatus melanoma: epidemiological, clinical and histopathological analysis. Dermatol Rev 2011, 98, 384-389.

2. Sobjanek M., Włodarkiewicz A., Urban M., Toboła J.: Czerniak aparatu paznokciowego. Dermatol Estet 2007, 9, 18-24.

3. Sobjanek M., Michajłowski I., Biernat W., Włodarkiewicz A., Nowicki R.: Clinical and dermoscopic features of nail apparatus pigmentations. Dermatol Rev 2013, 100, 65-79.

4. Sobjanek M., Włodarkiewicz A., Toboła J.: Original paper Melanonychia longitudinalis. Adv Dermatol Allergol 2006, 23, 130-137.

5. Perrin C., Michiels J.F., Boyer J., Ambrosetti D.: Melanocytes pattern in the normal nail, with special reference to nail bed melanocytes. Am J Dermatopathol 2018, 40, 180-184.

6. Blundo A., Cignoni A., Banfi T., Ciuti G.: Comparative analysis of diagnostic techniques for melanoma detection: a systematic review of diagnostic test accuracy studies and meta-analysis. Front Med 2021, 8, 637069.

7. Redi U., Marruzzo G., Lovero S., Khokhar H.T., Lo Torto F., Ribuffo D.: Acral lentiginous melanoma: a retrospective study. J Cosmet Dermatol 2021, 20, 1813-1820.

8. Durbec F., Martin L., Derancourt C., Grange F.: Melanoma of the hand and foot: epidemiological, prognostic and genetic features. A systematic review. Br J Dermatol 2012, 166, 727-739.

9. Ishii L., Richmond N.A., Carstens S.J., Vincek V.: An amelanotic nail bed melanoma presenting as persistent onychodystrophy. Dermatol Online J 2018, 24, 13030/qt3jj8z264.

10. Rangwala S., Hunt C., Modi G., Krishnan B., Orengo I.: Amelanotic subungual melanoma after trauma: an unusual clinical presentation. Dermatol Online J 2011, 17, 8.

11. Cahill S., Cryer J.R., Otter S.J., Ramesar K.: An amelanotic malignant melanoma masquerading as hypergranulation tissue Foot Ankle Surg 2009, 15, 158-160.

12. Ghariani N., Boussofara L., Kenani N., Ghannouchi N., Mebazaa A., Denguezli M., et al.: Post traumatic amelanotic subungual melanoma. Dermatol Online J 2008, 14, 13.

13. Lemont H., Brady J.: Amelanotic melanoma masquerading as an ingrown toenail. J Am Podiatr Med Assoc 2002, 92, 306-307.

14. Matsuta M., Segawa I., Akasaka T., Kon S., Nara T., Minato S.: A case of subungual amelanotic malignant melanoma: an electron microscopic study of aberrant melanosomes. J Cutan Pathol 1990, 17, 246-250.

15. Nakamura S., Nishihara K., Hoshi K., Itoh F., Nakayama K.: Subungual amelanotic malignant melanoma. J Dermatol 1985, $12,530-533$

16. Riahi R.R., Cohen P.R., Goldberg L.H.: Subungual amelanotic melanoma masquerading as onychomycosis. Cureus 2018, 10, e2307.

17. Winslet M., Tejan J.: Subungual amelanotic melanoma: a diagnostic pitfall. Postgrad Med J 1990, 66, 200-202.

18. Arican O., Sasmaz S., Coban Y.K., Ciralik H.: Subungual amelanotic malignant melanoma. Saudi Med J 2006, 27, 247-249.

19. André J., Moulonguet I., Goettmann-Bonvallot S.: In situ amelanotic melanoma of the nail unit mimicking lichen planus: report of 3 cases. Arch Dermatol 2010, 146, 418-421. 
20. Girgenti V., Balice Y., Cavicchini S., Fiorani R., Gianotti R., Veraldi S.: One ulcer and two nodules on the foot: a quiz. Diagnosis: subungual ulcerative amelanotic nail apparatus melanoma with giant nodular pigmented satellite metastases. Acta Derm Venereol 2013, 93, 124-125.

21. Harwood M., Telang G.H., Robinson-Bostom L., Jellinek N.: Melanoma and squamous cell carcinoma on different nails of the same hand. J Am Acad Dermatol 2008, 58, 323-326.

22. Boni A., Chu E.Y., Rubin A.I.: Routine nail clipping leads to the diagnosis of amelanotic nail unit melanoma in a young construction worker. J Cutan Pathol 2015, 42, 505-509.

23. Dika E., Patrizi A., Fanti P.A., Christman H., Misciali C., Piraccini B.M.: An asymptomatic subungual nodule. J Am Acad Dermatol 2016, 74, e27-e28.

Received: 30.08 .2021

Accepted: 5.09.2021

Otrzymano: $30.08 .2021 \mathrm{r}$.

Zaakceptowano: $5.09 .2021 \mathrm{r}$. 